\title{
The use of computer simulations and measurements in determining the energy efficiency of photovoltaic installations
}

\author{
Artur Bugała ${ }^{1, *}$, and Karol Bednarek ${ }^{1}$ \\ ${ }^{1}$ Poznan University of Technology, Institute of Electrical Engineering and Electronics, Piotrowo 3a Street, 60-965 Poznań, Poland
}

\begin{abstract}
The paper presents an analysis of the energy efficiency of a photovoltaic installation connected to the AC power grid. Forecasting of energy yield was carried out in two ways: with the use of PVSol software, as well as physical measurements of daily electricity production. On that basis, a statistical correlation between the results obtained from measurements and computer calculations was determined.
\end{abstract}

\section{Introduction}

Electricity is used in all areas of human business and private activity, therefore its rational production, storage and use is particularly important [1-3]. Most human activities are carried out in to achieve the best results of taken initiatives due to selected criteria [4-8].Various types of deterministic or stochastic optimization methods are used, as well as computer simulations and physical tests, in order to achieve high efficiency in the field of raw materials and energy management, object sustainability management, quality of supplied energy, check the profitability of undertaken investments or determine the profitability of production [4-14].

The paper deals with determining the energy efficiency of a photovoltaic installations [14-20]. Analyzes in this area were carried out in two ways: on the basis of computer calculations, using PVSol software and on the basis of physical measurements of daily electric energy from photovoltaic conversion [21]. The aim of the considerations is to develop tools (computer simulations) for the implementation of economic calculations and estimation of the return time of investment outlays related to the analysis of the legitimacy of using ecological energy sources.

\section{Research object}

The research object is a roof photovoltaic microinstallation with a nominal power of $3 \mathrm{~kW}$ located $96 \mathrm{~km}$ from Poznan in the north-east direction (Wielkopolskie voivodship).

The installation is equipped with $12 \mathrm{PV}$ modules (Yingli Solar model YL250P-29b) with a power of $250 \mathrm{~W}$, arranged in two strings. Photovoltaic modules are inclined at an angle of $30^{\circ}$ to the horizontal plane, while the receiver azimuth angle is about $10^{\circ}$ (southwest direction). The DC/AC power conversion was carried out using Steca Stecagrid 3000 inverter.

\section{Research and simulation results}

The on-grid photovoltaic installation was connected to the power grid in 2015 and enables the production of electric energy in the settlement system consisting in its transmission taking into account the energy consumption in a given balancing period. The obligation to purchase electricity arises from the first day of its connection to the distribution network and lasts for the next 15 years.

The presented measurement results, registered using prepared system consisting of a wireless communication gateway, DC/AC inverters, an external data server and a private user profile, are a measurement samples from the period July 2016 - June 2017. In order to compare the measurement results with the estimated values, a computer Valentin PVSol software was used [21, 22]. In order to improve the accuracy of the simulations, data of solar irradiance from the meteorological station located in the city of Piła was implemented.

Figure 1 shows the annual electricity production for the analyzed photovoltaic installation including measurement results and computer simulations.

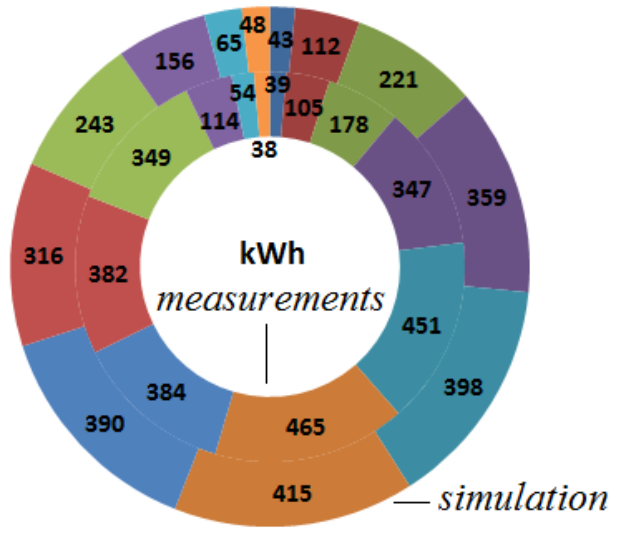
Eanuary
- February
March
april
May
June
July
august
September
noctober
November
December

Fig. 1. The annual value of electricity from photovoltaic conversion for an installation with a nominal power of $3 \mathrm{~kW}$.

\footnotetext{
*orresponding author: artur.bugala@put.poznan.pl
} 


\section{Statistical analysis}

The assessment of correlation of the measurement results and computer simulation was carried out using selected statistical tools in the form of root mean square error (RMSE), mean bias error $(M B E)$ and Pearson correlation coefficient $k$ [21, 23-26]:

$$
\begin{gathered}
R M S E \%=\frac{\sqrt{\frac{\sum\left(C_{i}-M_{i}\right)^{2}}{n}}}{\bar{M}} 100 \% \\
M B E \%=\frac{\frac{\sum\left(C_{i}-M_{i}\right)}{n}}{\bar{M}} 100 \% \\
k=\frac{\sum_{i=1}^{N}\left(C_{i}-\bar{C}\right)\left(M_{i}-\bar{M}\right)}{\sqrt{\left[\sum_{i=1}^{N}\left(C_{i}-\bar{C}\right)^{2}\right]\left[\sum_{i=1}^{N}\left(M_{i}-\bar{M}\right)^{2}\right]}}
\end{gathered}
$$

where: $M_{i}-$ measured value of the electric energy, $C_{i}$ - calculated value of the electric energy, $n$ - sample size, $M$ - average value of the measured quantity, $C$ - average value of the calculated quantity. The results of the calculations are presented in Table 1.

Table 1. Results of statistical analysis including RMSE\%, $\mathrm{MBE} \%$ and Pearson correlation coefficient.

\begin{tabular}{|c|c|c|}
\hline RMSE\% & MBE\% & k \\
\hline$[\%]$ & {$[\%]$} & {$[-]$} \\
\hline 21,05 & $-4,450$ & 0,95 \\
\hline
\end{tabular}

\section{Conclusions}

In the case of the analyzed installation, the results of the simulation turned out to be beneficial for the investor due to the increased electric energy production in relation to the value assumed at the design stage. The exception are the months of October and March, in which the value of electricity production is about $37 \%$ and $24 \%$ lower than estimated.

The average value of electricity, determined for a full measurement year, based on the results of measurements and simulation analysis, is respectively $242.2 \mathrm{kWh}$ and $230.5 \mathrm{kWh}$. Based on the conducted analysis, $4.5 \%$ underestimation of the value of electricity in relation to the measured value was observed. The value of the RMSE\% parameter, exceeding $21 \%$, indicates the occurrence of months for which there are significant discrepancies between the results of measurements and calculations (May, September, October).

\section{References}

1. J. Jajczyk, A. Dobrzycki, M. Filipiak, D. Kurz, E3S Web of Conferences, 19, 01027 (2017)

2. J. Jurasz, A. Piasecki, E3S Web of Conferences, 14, 01017 (2017)
3. L. Kasprzyk, Eksploat. Niezawodn. 19, 229-236 (2017)

4. K. Bednarek, R. Nawrowski, A. Tomczewski, International Conference on Parallel Computing in Electrical Engineering (PARELEC, 218-222, 2000)

5. J. Jajczyk, Computational Problems of Electrical Engineering, 1-3 (IEEE Xplore, Sandomierz, 2016)

6. L. Kasprzyk, A. Tomczewski, K. Bednarek, Prz. Elektrotechniczny 87/12b, 82-85 (2011)

7. L. Nowak, Ł. Knypiński, C. Jędryczka, K. Kowalski, COMPEL 34, 496-504 (2015)

8. R. Wojciechowski, Archives of electrical engineering 65/3, 601-611 (2016)

9. K. Bednarek, Int. J. Occup. Saf. Ergon. (JOSE) 16, 357-368 (2010)

10. L. Kasprzyk, A. Tomczewski, K. Bednarek, A. Bugała, E3S Web of Conferences 19, 01030 (2017)

11. M. Lebioda, J. Rymaszewski, E. Korzeniewska, Journal of Physics Conference Series 494, 012018 (2016)

12. Ł. Putz, D. Typańska, Prz. Elektrotechniczny 90/3, 111-114 (2014)

13. J. Szymenderski. D. Typańska, Computational Problems of Electrical Engineering, 1-3 (IEEE Xplore, Sandomierz, 2016)

14. G. Trzmiel, Eksploat. Niezawodn. 19, 516-521 (2017)

15. C. Augustine, M. Nabuchi, The Pacific Journal of Science and Technology 1, 693-700 (2009)

16. A. Bugała, G. Frydrychowicz-Jastrzębska, D. Janczak, J. Dach, P. Boniecki, International Multidisciplinary Scientific Geoconference (SGEM, 337-344, 2016)

17. A. Bugała, G. Frydrychowicz-Jastrzębska, D. Janczak, W. Czekała, J. Dach, M. Zaborowicz, International Conference on Energy and Environment, (ICEE, 721-727, 2015)

18. A. Bugała, G. Frydrychowicz-Jastrzębska, Z. Zbytek, J. Dach, D. Janczak, International Conference on Frontiers of Sensors Technologies (ICFST, 2016), MATEC Web of Conferences, 59 (2016)

19. G. Frydrychowicz-Jastrzębska, A. Bugała, Energies 8/2, 1025-1041 (2015)

20. D. Głuchy, D. Kurz. G. Trzmiel, Prz. Elektrotech. 90/4, 78-80 (2014)

21. A. Bugała, K. Bednarek, Pozn. Univ. Technol. Acad. J. Electr. Eng. 94, 235-244 (2018)

22. www.solargis.info

23. A. Bugała, K. Bednarek, L. Kasprzyk, A. Tomczewski, E3S Web of Conferences, 19, 01002 (2017)

24. G. S. Maddala, Ekonometria (PWN, W-wa, 2014)

25. M. Sobczyk, Statystyka (PWN, Warszawa, 2016)

26. A. Zeliaś, Metody statystyczne, (PWE, W-wa, 2000) 